\title{
新形势下财务会计向管理会计的转型分析
}

\author{
罗娟 \\ 云南经济管理学院 \\ DOI:10.32629/ej.v2i3.146
}

[摘 要] 随着我国经济的飞速发展,对我国许多企业的财务方向带来了巨大的冲击,在以前,我国的财务政策基本上都是属于 财务会计,但现在财务会计基本上满足不了企业的需求,越来越多的企业开始向管理会计拓展,最主要是现在国家也大力提倡 企业财务会计向管理会计进行过渡,让管理会计成为企业发展的核心,本文主要阐述了一下财务会计向管理会计转变中有哪些 新措施。

[关键词]财务会计; 管理会计; 转型

\section{1 财务会计的内涵}

1.1 财务会计的定义

财务会计是执行企业会计准则, 在会计主体、持续经营、 会计分期和货币计量的基本假设前提下、遵循权责发生制等 会计信息质量要求, 对经济业务进行确认、计量和报告, 为与 企业有经济利害关系的有关方面提供关于企业财务状况、经 营成果、现金流量等信息的经济管理活动。

1.2 财务会计的作用

财务会计是企业重要的基础性工作, 具有核算和监督的 职能, 通过会计程序, 可以系统地将特定会计主体所发生的 财务事项表现出来, 如实、及时、全面反映企业经济活动, 为相关主体提供决策依据。通过会计数据分析, 考核企业财 务计划执行情况, 发现经营活动中存在的问题, 找出差距及 原因, 从而总结经验, 提出改进的建议和措施, 进一步提高企 业经济效益, 而会计监督职能的发挥利于企业堵塞经营管理 中的漏洞, 进一步规范自身行为, 促进企业可持续发展。

\section{2 管理会计的特点}

管理会计又称 “内部报告会计”, 是企业为了强化自身 经营, 提高经济效益, 方便内部管理所采取的一系列专业的 管理办法。管理会计侧重服务于企业内部各级管理者, 面向 企业未来发展, 向管理者提供与企业战略发展、经营规划有 关的生产经营活动信息, 帮助决策者做出提高企业经济效益 的有利决策。管理会计不受会计准则的约束, 吸收借鉴了微 观经济学、现代数学的理论和方法, 其方法和程序具有很大 的灵活性。管理会计可以从企业整体、企业内部责任主体等 不同层次反映企业的经营活动。

\section{3 财务会计与管理会计的关系特征}

财务会计和管理会计都属于会计学科, 两者之间既有联 系, 又存在巨大差别, 其关系特征主要表现在两个方面: 一方 面是关联性: 两者的起源一致, 均源自于传统会计, 两者的基 础理论相同; 两者的核算对象相同, 均为企业的经济活动; 两者的目标也一致, 都是向企业提供数据信息, 而企业的管 理层依据此信息, 作出适合企业发展的决策, 从而提升企业 的利润空间。另一方面是差异性: 财务会计和管理会计的服
务对象有差异：管理会计的服务对象为企业内部的管理层, 而财务会计则只需要客观、真实地核算企业的财务状况, 形 成统一财务报告即可; 核算方法有差异: 财务会计的核算方 法比较简单, 依靠基本的会计知识就能得出数据, 而管理会 计则在财务会计的核算方法的基础上, 还需考虑运用统计学 和数学的方法, 对企业的决策、预算、成本进行分析, 同时管 理会计人员还需具备经济学和管理学的知识, 从而才能从宏 观方面把握企业发展的方向。

\section{4 管理会计和财务会计的不同点}

我们都知道会计分为财务会计和管理会计。我们对于会 计的理解可能认为会计仅仅是一类人的职业, 实际上并不是 这样, 会计是企业财务当中的一门功课, 那么财务会计就属 于会计的一种, 财务会计主要是对企业日常的一些账目进行 计算、登记和制作财务报表, 说白了, 财务会计就相当于做流 水账一样, 将企业的支出、收入做成报表报给企业领导者或 者上报税务局。而管理会计主要是针对自己对企业账目的一 些了解进行合算和分析, 并帮助企业的管理者为企业提供一 些好的建议和措施, 帮助企业发展。财务会计和管理会计在 企业当中都有其一席之地, 都能给企业带来帮助。但是, 财务 会计和管理会计有很多不一样的地方。首先来说, 财务会计 可以是外部人员, 也就说企业可以花钱去会计事务所或者一 些私人机构去请专业的会计来对企业的账目进行核算, 这些 会计人员的目的很简单, 就是帮助企业把帐算完报到税务局 就可以了。那么管理会计就不一样了, 管理会计主要是将财 务会计的报表以及公司的各类税收、支出以及收入进行统计 和规划, 帮助公司提出一些合理化的建议。通过公司的财政 管理帮助公司的领导者正确的管理整个公司。说白了, 管理 会计主要就是帮助企业进行发展、帮助企业获得最大的利润, 同时预测企业今后未来会发生的状况。这是管理会计真正的 存在价值。

\section{5 财务会计向管理会计转型的必要性}

财务会计向管理会计转型已经成为企业未来的发展趋 势, 这是由于管理会计自身具备极大优势, 如管理会计可根 据企业特点, 合理推断国家经济发展趋势, 帮助企业掌握发 
展先机, 达到提升企业综合竞争力的目的; 管理会计还能通 过对企业内部各层级信息的分析, 为企业运营决策提供可靠 依据, 帮助管理者完善企业的内控制度。

随着我国社会经济大环境的不断变化和现代科技的广 泛应用, 国家要求企业提高自身管理水平, 而财务会计无法 参与企业管理数据的核算工作, 也无法胜任大数据信息处 理、互联网应用工作, 更无法对企业经济活动给出评估建议 和决策信息, 与之相反, 管理会计则具有以上职能, 能对企业 的经济活动和发展方向全面把握, 因此, 管理会计的重要性 远远超过财务会计。

\section{6 财务会计向管理会计转型的新举措}

6. 1 增加财务会计处理业务能力的整体水平

实际上管理会计和财务会计在本质上有很大的区别, 但 其职能基本上是一样的。其最基础的工作都是对企业的账目 进行核算。如果仅仅让财务会计马上转为管理会计, 那是不 可能的。企业要增强财务会计处理业务能力的整体水平, 让 其慢慢转变为管理会计。针对这种情况笔者有两点建议。第 一, 企业在招聘会计的时候可以直接招聘专业的管理会计; 第二, 企业要经常对财务会计进行培训, 并找专业的管理会 计进行教授, 让公司的财务会计逐渐领会精神、逐渐学习、 增加自身的业务能力和水平, 最后逐步转变成管理会计对企 业进行管理。

6. 2 对财务会计进行合理的安排

公司应应该对财务会计进行合理的安排, 不再让公司的 财务会计仅仅管理公司的账目。在公司开董事会或者其他会 议的时候, 应该让公司的财务会计进行参与, 让其了解公司 现阶段的情况, 让其逐步走进公司的管理层。只有财务会计 走进了公司的管理层, 其才能够慢慢向管理会计转变。当财 务会计听了公司发展的会议之后, 便可以根据公司的账目等 情况, 对公司展开合理化的建议, 虽然提出的建议可能不是 那么理想, 但是只有这样才能锻炼财务会计的整体水平。如 果公司有管理会计的话, 让管理会计和财务会计进行合作, 这样双方都能得到提高。

\section{3 引进和培训财务管理人才}

企业想要提高自身的管理能力, 转变财务会计势在必 行。针对我国企业存在的管理会计人才缺乏的问题, 企业可 从两个方面入手: 一方面是培养企业内部的会计人员的管理 能力: 首先, 需要转变企业会计人员的思想观念, 管理会计的
工作与传统会计不同, 企业在强化其专业知识和技能的基础 上, 还需要为其提供管理知识的培训课程, 如聘请专业的管 理会计教师向会计人员教授管理业务、金融经济等理论知识 也可定期组织会计人员到相应的管理会计学校深造, 提升会 计人员的综合能力。其次, 企业还要为培训过的会计人员提 供实践场地, 帮助其迅速成长。对于实践检验中能力较强的 会计人员, 企业管理层需给予其更多的管理权限, 为其营造 发挥空间, 让其真正融入企业的管理中, 将所学应用到企业 的发展中, 提升企业的管理水平。

6.4 优化会计核算队伍

企业要优化会计核算队伍。现阶段企业中进行计算、核 算的人员实在是太多了, 企业要精简这些人员, 将核算人员 当中的部分人员进行管理会计的培训, 让核算会计逐步转变 成管理会计, 通过这种方式来增加公司财务部核算人员的效 率, 同时也不会让公司财务部核算人员的队伍过于庞大, 公 司也能够听从更多的合理化建议来提高公司整体的发展。

6.5 明确管理会计的定位

公司一定要把管理会计和财务会计进行合理定位。作为 一个企业来讲, 要把管理会计作为公司的主要参与者, 只有 把管理会计摆正到正确的位置后, 才能让管理会计发挥其作 用, 企业要给管理会计一定的权限和权利。让管理会计真正 发挥它的职能, 起到对公司管理的作用。同时财务部门也要 和其它部门做好协商, 共同帮助公司发展。

\section{7 结束语}

综上所述, 为适应不断变化发展的新经济体制, 寻求一 条可持续发展道路, 企业需要抓住时机, 推动财务会计向管 理会计转型, 从而增强财务人员的业务技能和综合素质, 提 高企业财务信息的价值。

\section{[参考文献]}

[1]张丽桃.新形势下财务会计向管理会计的转型与融 合 $[J]$. 财会学习,2017,(21):151.

[2]裴淑芹.新形势下财务会计向管理会计的转型与融合 研究[J].财讯,2018,(20):29。

[3]佟梅.浅议新形势下财务会计向管理会计的转型[J]. 中国管理信息化,2018,21(22):14-15.

[4]赎宇娇.新形势下财务会计向管理会计的转型与融合 研究[J].山西农经,2018,(10):88. 